\title{
Football in Turkey from 1960 to Present Day: Unpreventable Violence
}

\author{
Servet Reyhan \\ Correspondence: Servet Reyhan, Department of Physical Education and Sports, Siirt University, Turkey.
}

Received: May 17, 2019

doi:10.11114/jets.v7i9.4351

Accepted: June 24, 2019

Online Published: June 27, 2019

URL: https://doi.org/10.11114/jets.v7i9.4351

\begin{abstract}
This study seeks to investigate the issue of violence in football in Turkey from 1960 up to present day along with incidents, riots and stampedes that occurred related to violence in football. The study was conducted considering three main periods, which are from 1960 to 1980, 1980 to 2000 and finally 2000 and today. The reason why these particular periods were chosen was that each period had its own characteristics related to football-related violence and other aspects that affected it. To collect data, 15 members of fan groups were interviewed related to the football-related violence. Furthermore, the study took into account not only physical aspect of violence but also social and psychological aspect of it. Findings revealed that Turkey has been a country where football-related violence has never been completely prevented due to reasons such as coups, coup attempts, political issues, social behaviors shaped by these political issues, regulations and media considering these periods. And based on the participant opinions, it was found that main actors responsible for the violence are top officials in the football federation, politicians and media. As a result, football-related violence remains to be a major problem in football games not only on the pitch but also off the pitch.
\end{abstract}

Keywords: football-related violence, coups, Turkey, hooliganism, football industry

\section{Introduction}

Football is a form of game that is extremely common and in great demand all over the world along with its all aspects. Nearly every single country has indigenised this particular type of sports. It is unknown where and when exactly football was invented. However, according to Federation Internationale de Football Association (FIFA), the contemporary history of the world's favourite game spans more than 100 years and it all began in 1863 in England, when rugby football and association football branched off on their different courses and the Football Association in England was formed (Fifa.com). In the wake of this development, professional leagues that encompassed games among rivals were launched and spread all over the world. Football did not remain to be confined to solely English territory and was adopted by a great many countries where it was considered as the favourite game. In fact, the occasion that made football so popular was the inaugural FIFA World Cup which was hosted by Uruguay in 1930. It was that time when people started to regard football not merely as a game but as a lifestyle as well as industry. This perspective led to the formation of various groups that subsequently affected the football game both positively and negatively. In a positive manner, football made people unite regardless of their race, socioeconomic status, education level and many other aspects. On the other hand, it also brought about a plethora of unfavourable issues that have not come to an end up to now. Among these unfavourable issues are hooliganism, aggression, riots, protests, violence and match-fixing. In fact, this study will mainly focus on the issue of violence as violence has never been prevented completely despite all the measures taken by governing bodies as well as football associations. Violence is definitely opposed to the idea of the invention of football as football is a type of sports and refers to tolerance, entertainment and mental comfort. Football is under the undesirable impact of violence with problems related to violence that occurs all over the world. Unfortunately, this is the case in every country though in various degrees. One of these countries where violence is experienced densely in football games is Turkey.

This study will basically touch upon violence in football and violent on-pitch as well as off-pitch incidents in Turkey from the very beginning of 1960 up to now. The year 1960 was taken as basis as professional leagues were launched in 1959 in Turkey. Besides, the study will include the opinions of the participants in the study who were interviewed related to the football-related violence.

This study will go on with a literature review in the second section, a discussion of violence in football between 1960 and 1980, between 1980 and 2000, and 2000 and today in the third, fourth and fifth section respectively. Finally, there will be the methodology section, a discussion of unpreventable violence and a conclusion. 


\section{Literature Review}

It is observed that the issue of violence in football has scarcely been studied when literature is reviewed. Besides, the main points that have been taken into account are hooliganism which has its origin in English territories and subsequently spread all over the world and identities related to football violence. Among the scholars who have devoted time to carrying out international researches upon violence in football are Giovanni Carnibella et al. (1996), Martha Newson (2017), Ramon Spaaij (2008), Eric Dunning (1999), Jamie Cleland and Ellis Cashmore (2016) and Joel Rookwood\& Geoff Pearson (2012). In their study titled as Football Violence in Europe Carnibella et al. (1996) stated that the game of football has been associated with violence since its beginnings in 13th century England. They reported that 'football hooliganism' originated in England in the early 1960s, and has been linked with the televising of matches and with the 'reclaiming' of the game by the working classes (ibid, p. 5). They also pointed out in their cross-national variations that Britain is not the only country where violence in football occurs and that countries including Germany, the Netherlands and Belgium have significant problems with similar levels of football-related violence (ibid. p. 7). In his study Football, Fan Violence, and Identity Fusion, which takes into consideration a cognitive approach to the phenomenon of football violence, Newson (2017) discussed two football cultures, one of which is in UK and the other of which is in Brazil to illustrate the ways in which identity fusion can help understandings of football violence. According to Newson (2017), as fan groups invest much time and financial sources in their teams' events and display visual symbols of allegiance to their teams, a particular inter-group social bonding occurs. Furthermore, Ramon Spaaij (2008) stated in his study called Men Like Us, Boys Like Them: Violence, Masculinity and Collective Identity in Football Hooliganism that football hooliganism is a complex, heterogeneous and dynamic phenomenon that should be studied in its different social and historical contexts and that the search for a general theory of football-related violence therefore seems misleading and futile. Besides, he argues that there exist some striking commonalities in the collective identifications of football hooligan formations in different national and local contexts (ibid. p. 3).

As regards researches on football-related violence in Turkey, the country which is taken as basis in this study, it is seen that scholars in this field have mainly focused on national and local issues superficially in their studies (Çakmak and Çelik, 2016; Bulgu, 2005; İlhan, 2014; Yücel et al., 2015). As pointed out by Carnibella et al. (1996), Turkey is among the countries including Greece, the Czech Republic and Albania which were in the early stages of football-related violence in mid-1990s and where sporadic violence was also reported along with isolated incidents. As of mid-1990s, Turkey has experienced a plethora of violent incidents related to football. Therefore, this issue should be handled in a great many contexts and with different approaches to fully grasp why football-related violence occurs in Turkey and how it should be prevented. This study will attempt to deal with the causes and analysis of football-related violence in Turkey and potential measures that were and can be taken to prevent this phenomenon to a great extent.

\subsection{From 1960 to 1980}

Until the 1960s, the world experienced huge turmoil due to two world wars that had destroyed the whole world not only socially and economically but also politically and psychologically. Having struggled to dress the wounds stemming from these wars, the world was trying to find solutions to create a new world order. In fact, football was an inevitable part of this chaos that also affected huge groups. Besides, football was also used by dictatorships as a means of propaganda to have an impact on these groups. For instance, as Eric Niiler (2018) pointed out, Adolf Hitler was hoping for a bit of revenge after losing the propaganda battle at the 1936 Berlin Olympics. It is also stated by Niiler that Global tournaments like the World Cup are never free of politics and that was especially true in 1938 during the run-up to World War II when the fascist leaders of Germany and Italy were eager to put their stamp on the final outcome and that those games were supposed to be a showcase for the Nazi regime and the athletic superiority of the Aryan race.

However, in spite of all measures taken by governing bodies, violence in football remained to be out there. For, the turmoil that arose from all these factors led football to be used as a means of expressing reactions with or without groups they belong to. That being said, football violence turned into a major problem after the 1960 s with on-pitch and off-pitch riots and stampedes that were triggered by team supporters who are called as hooligans today. Among these riots were those that occurred in countries including England, Peru, Argentine, Germany, Italy and Congo though the list is not exhaustive. One of these countries that had its share is Turkey where football violence was sometimes at the top of the agenda.

Turkey underwent major problems particularly arising from military-based administrations among which were coups and memorandums in the 1960s and 1970s. The violent atmosphere that was created by figures at senior positions during these years influenced the society in an unfavourable way. The affected society tended to keep away from violence in football, which can be thought to be a partially low-level type of violence. On the other hand, the two worst incidents that occurred in the football history of Turkey concurred between 1960 and 1980 when coups and memorandums were preeminent issues. The worst incident occurred between the fans of Kayserispor and Sivasspor 
clubs at the Atatürk Stadium of Kayseri in Turkey. After the home team went to leading by a goal in the half time, supporters of both teams started to bully and annoy each other with rocks in hands. These supporters were also armed with knives, pistols and many other weapons that led to a much bigger riot that overflowed the pitch. The stampede that was caused by the fleeing crowd in front of the stand exits resulted in more than 40 deaths and at least 300 injuries. Incidents did not stop even after the game and spread all over the both cities so that the Turkish government had to intervene in for resettle. The second one occurred between the soccer teams Kirıkale and Tarsus, leading to 4 deaths and more than 100 injuries. It broke out after the football players of the two teams fought each other before the game began. Thus, the match was postponed to a further date. During the match day, there were provocations by Kırıkkale supporters who wrote "Death to Tarsus people" or "Champion Kırıkkalespor" on high hills and 10 buses full of supporters of Tarsus club came to Kirıkkale city to support their team. They were given 450 tickets to enter in the stadium but the stand that was allocated for them had room for only 200 people. The first half time ended with $0-0$ draw and after the second half time whistle was blown, both teams scored goals to end the match with 1-1 draw. After the end of the match, as the goalkeeper of the home team punched the goal scorer of the away team, the fuse was ignited and the players of both teams launched a stampede and resulted in a riot that would involve the angry supporters of both teams.

Though these matches are considered as the worst ones of the football history in Turkey, there were also small-scaled incidents that can be discussed in another study as the main point of this paper is to highlight the most severe occasions that occurred related to violence in football.

\subsection{From 1980 to 2000}

At the very beginning of 1980, Turkey was exposed another coup by the military that was considered the most effective one as the coup was staged against not a single ideology or social group but against the whole country. The figures that were involved in the coup had a rather oppressive regime that silenced and suppression the whole society resulting in curfews and an immobilization within the country. Thus, it can be implied that neither ordinary people nor football supporters could dare take to the streets or trigger a riot. As a result, the 1980s did not see any football-related violence and incidents due to the abovementioned suppression that was applicable at that time. Though the oppressive regime was overthrown in the late 1980s and thus football-related violence slightly erupted, the period between the 1980s and 2000 saw highly small-scaled incidents. One of these matches occurred during a match between Kocaelispor and Ankaragücü clubs when supporters had a fight due to disagreement over their seats. Following the fight, a supporter was shot dead.

As the Turkish society was on the verge of undergoing a huge transformation, these days referred to reconciliation among rivals and thus supporters who decided to bring peace to stands as they believed there was no benefit for anybody involved in football to trigger riots and lead to deaths. Yet, it is also possible to state that as of the mid-1990s, media stepped in and was the precursor of a new era in football which would be totally associated with violence. This era would start off from the very beginning of the millennium.

\subsection{From 2000 up to Today}

In the wake of developments triggered by the power of media and considering football as an industry as well as booms in the level of success of Turkish football clubs both in their own league and international tournaments, the football culture and on-pitch and off-pitch reactions of supporters were reshaped and brought into a new dimension. Besides, Turkey underwent a huge change as the country grappled with economic crisis that emerged from the very beginning of the millennium. Thus, this crisis could not be expected to bypass the football industry. Along with economic collapse as well as continual elections, the society was striving to find a way out. As Turkish society has enormous admiration for football, the members of this society were regarding football and stands as phenomena to relieve and get out of stress by feeling the sense of belonging to a specific club or group. Among the particular groups of supporters that are known to have been established long ago are Çarşı for Beşiktaş club, UltraAslan for Galatasaray club, Genç Fenerbahçeliler for Fenerbahçe club, Texas for Bursaspor club and Nefer for Eskişehirspor club and so on. However, discourses of media and executives of top clubs, reactions of security forces and football federations have a crucial but negative role in reshaping and worsening the situation which has a huge impact on stands and supporters. All these factors have created a violent atmosphere that is unable to be prevented.

Özgen and Balc1 (2017) revealed that the violent events in the stadiums differentiate depending on the ages and educational levels of the fans as well as on how often they watch matches.

Özgen and Argan (2017) found that the arrogances of the fans differentiate depending on how often they watch matches.

Some of the most unfavourable incidents occurred in the 2000s. In 2000, two Leeds United fans were killed in violent clashes between English and Turkish football supporters in Istanbul and another man was seriously injured after 
fighting ahead of UEFA Cup clash between the Premiership side and Galatasaray (BBC, 2000). In 2002, the match between Beşiktaş and Trabzonspor ended 5-0. After the end of the match, the supporters of defeated team Trabzonspor took revenge by removing the seats of the stadium and scattering them all over the pitch resulting in a riot that would provoke the supporters of rivals later on. In another match that was played in 2002 between Fenerbahçe and Galatasaray, the two top clubs of Turkish football that have been in an eternal rivalry for a long time, Fenerbahçe won the match with $6-0$, and the goalkeeping coach of the away team was injured with hard objects coming from the stands. This incident overshadowed the victory of the home team. Such relatively small-scaled incidents were followed by worse incidents afterwards. In 2004, Beşiktaş and Çaykur Rizespor took on and as reported by UEFA (2004), sixteen-year-old Cihat Aktas died after receiving two stab wounds when fighting broke out among a section of home supporters at half-time during the match at the Inönü stadium in Istanbul. According to the report, Aktas was taken to hospital but died subsequently (ibid, 2004). In 2005, Fenerbahçe hosted the British football club Everton for a scrimmage before the season started and had won the match with the score of 5-0, and a fan named Yusuf Behar was shot in his leg and the source of bullet was not found (Tinaz et al., 2015). Having travelled to the airport after the match between Fenerbahçe and Çaykur Rizespor, some people who were then identified as Trabzonspor supporters shot the driver of the bus that was en route and transported the Fenerbahçe football club and fortunately, the head of security sitting next to the driver stepped on the brakes and prevented a potential disaster. And finally, in 2019 Amedspor Faaliyetler and Sakaryaspor A.Ş. had a match which would never be forgotten due to an unprecedented occasion. Mansur Çalar, the captain of the home team Amedspor Faaliyetler, slashed the players of the away team while the match was going on and had a lifetime ban with licence revocation.

\subsection{Unpreventable Violence}

Particularly as of 2010, nearly all the stadiums in Turkey were renovated, technological devices were used at all stadiums, new laws and schemes were introduced, punishments and security measures were intensified. However, the issue of violence still remained as a major problem with rise in the number of violent incidents though statistically the number of deaths and wounds remarkably decreased. One of the outstanding developments that occurred related to violence in sports and football, as violence was mainly associated with football, was the introduction of the law numbered 6222 on the Prevention of Violence and Disorder in Sports in July 2011. This law also brought with it the introduction of Passolig e-ticket scheme that required supporters to have a card in order to participate in matches. In fact, this has a correlation with actions that were carried out by British Football Association to prevent the hooliganism and violence in football. Through the use of measures taken by the police, legislation by the government and rules set in place by the English Football Association, England has taken the lead in regulating and preventing the problem (Footballnetwork, n.d.).

Despite all these measures and reforms as well as regulations and schemes, violence did not cease to be a major problem of sports and football as violence still occurs psychologically and physically on and out of the pitch. Turkey is one of the countries that still have much to do to prevent the violence in football as the society is not ready yet to overcome the issue completely. The term violence is so embodied in the society that it is not easy to totally eradicate this embodied feeling though it does not seem as bad as it was decades ago. Considering that the media in Turkey has an unfavourable stance towards supporters of football and supporters themselves have a disruptive discourse rather than a constructive one, it seems unlikely that violence will be removed from the minds of supporters and football fields. This fact also stems from the very nature of the Turkish society that approaches violence as a part of them. Indeed, Turkish people are very naïve and understanding people but they do not tend to exhibit this type of behaviour when violence is the case.

\section{Methodology}

\section{Sampling}

Data collection through in-depth interviews is highly popular among qualitative researches and provides in-depth information related to research phenomena. In this context, purposeful sampling was used to reach 15 members of football fan groups of the relevant periods to investigate the unpreventable violence in Turkish football during the periods in question. Patton (2002) states that in qualitative researches, the researcher may stop data collection process when data repeat themselves, and he defines this as the saturation point in data collection. As a result of the interviews conducted with the relevant fans, it was found that the saturation point presented by Patton (2002) was archived and data collection process was finished.

\section{Data Collection Tool}

A semi-structured interview form was prepared to conduct interviews with fans included in the study. The interview form approach expressed by McCracken (1988) was used. In this context, a literature review was carried out related to the research phenomena and an interview form including 5 questions in total was prepared by obtaining the opinions of academicians that have studies about violence in sport. 


\section{Data Collection}

Interviews were conducted in open public cafes in accordance with the procedure of the semi-structured interview. Silverman (1993) claims that researchers must stand of judgemental and directive reactions. In this context, the researcher has stood of being directive to remain neutral. Interviews lasted between 27 and 48 minutes. All interviews conducted as part of the study were recorded with a recorder. All data obtained during the in-depth interviews were recorded on computer

\section{Data Analysis}

Data obtained were analysed in accordance with basic methodological principles of the descriptive analysis. In this context, the N-vivo program, which is commonly employed in qualitative researches, was used. A coding list was formed from the most repeated data in this study. Four themes were formed by the researcher in line with the relevant coding list. The themes formed were given with a literature discussion related to the opinions of participants.

\section{Result}

Data obtained from participants were discussed and presented through four themes. In this sense, it was determined that there were four main factors that led to the occurrence of the football-related violence during the period in question in parallel with the opinions of the participants.

\section{The impact of media}

T-9

"Turkish Football Federation, Referees, Administrators, Fans, and media are the major responsible actors of the football-related violence."

\section{T-11}

"I think that those who are mainly responsible for the violence are administrators and media, and that there is a great deal of advertisement of football and people are provoked."

\section{The impact of referee}

\section{T-7}

"Decisions given by referees maximise the violence, thus referees should be given seminars and those who are capable should be assigned with the elimination of partisan referees. Biased referees should overcome bias and fans should be trained"

\section{T-4}

"Our referees should be neutral as a whole, and the football community, in particular the authorities, should concretize their abstract discourses against this situation, at least to contribute to decreasing the level of violence."

\section{The impact of administration}

T-3

"The only one, who is responsible for the violence, I believe, is those who administrate."

"The attitudes, statements, releases, and acts of the football club executives enhance the violence."

\section{The impact of politics}

\section{T-1}

"The statements of politicians that disrupt and dissociate the society also affect the sports and lead to the expression of violent feelings of people."

\section{T-10}

"The impact of politicians on the sports and football, and the belief that politicians favour some certain teams, though the football federation is autonomous, cause the fans of other teams to exhibit violent behaviours."

\section{Conclusion}

Violence has always been associated with football though the notion of violence is totally opposed to the idea that football is a game that involves entertainment, comfort, getting rid of stress and the union of people regardless of race, colour or any other characteristics. As of the very beginning of the inaugural World Cup up to now, violence has been out there either psychologically or physically and this has sometimes been carried out under the impact of political figures or events. Nearly every country on the map of the world has been exposed to football-related violence to a certain degree. Nonetheless, countries such as England, Argentine, Peru and Turkey have felt the very nature of 
football-related violence on their territories. In fact, hooliganism was coined by English people as it was first introduced by them. Turkey is one of the countries that could not eradicate football-related violence.

This paper focused on particular periods when violence in football was a huge problem and had to be taken care of. Based on the opinions of the participants that were included in the study, it was determined that people mainly think that those who are responsible are top officials in the industry and politicians as well as the media. Though they also think that referees should be trained at higher levels, referees are seen less problematic than other figures that may provoke the football-related violence.

Considering the period between 1960 and 1980, Turkey experienced one coup and one memorandum managed by the military and thus the society was extensively affected by these events, results of which could also be observed in football. Though there was no impact of media or other issues that could trigger violence in football in Turkey as technology was not advanced enough at that time, violence somehow occurred and this can be explained only through the violent atmosphere which was created by the two military-based events. Though Turks were struggling to bind up the wounds of a huge war that broke out at the beginning of the $20^{\text {th }}$ century, they found themselves in a violent atmosphere again when military-based events emerged. And this atmosphere negatively affected the football game as could be expected.

Considering the period between 1980 and 2000, the atmosphere was not so different from that of the 1960s and 1970s. Besides, Turkey underwent transformations and economic crisis along with coups or coup attempts. Though it is possible to mention that the violent culture that was created was trying to be eradicated with some peace processes among rival groups of supporters, the nature of violence was embodied in the society and would go on afterwards.

Finally, though the $21^{\text {st }}$ century can be considered as a period when the number of deaths and wounds due to violence in football decreased, violence was manifested psychologically in the minds of the society and supporters of football and regarded as an oppressive factor. This psychological barrier could not be blocked and led to the continuum of football-related violence, contributing to the formation of hate speech environment among rival groups of football supporters. Unfortunately, this atmosphere remained permanent in the minds of people who were involved in violence in football.

\section{References}

BBC, 6 April 2000. Fans killed in Turkey violence. Retrieved from http://news.bbc.co.uk/2/hi/europe/703283.stm

Bulgu, N. (2005). Sporda Şiddet ve alt Kültür, Hacettepe Spor Bilimleri Dergisi, 16(4).

Çakmak, M. N., \& Çelik, V. O. (2016). FutboldaŞiddet ve Erkelik: NeferTaraftarGrubuÖrneği, SosyolojiKonferansları No: 54

Carnibella, G., Fox, A., Fox, K., McCann, J., Marsh, J., \& Marsh, P. (1996). Football Violence in Europe - A Report to the Amsterdam Groupî, Mimeo, The Social Issue Research Centre, Oxford.

Cleland, J., \& Cashmore, E. (2016). Football fans' views of racism in British football, International Review for the Sociology of Sport, 5l(1), 27-43. https://doi.org/10.1177/1012690213506585

Dunning, E. (1999). Sport Matters: Sociological Studies of Sport, Violence and Civilization . London: Routledge

Fifa, (2019). [22.02.2019]. History of Football-The Origins. Retrieved from https://www.fifa.com/about-fifa/who-we-are/the-game/index.html

Football Network, (2019). [25.02.2019]. Preventing Football Hooliganismhttps://footballnetwork.org/violence/reduce-violence/

İlhan, E. (2014). Spor'daşiddetinulaştığıNokta; 17 Eylül 1967 Kayserispor-Sivassporkarşılaşması. KMÜ Sosyal ve EkonomikAraştırmalarDergisi. 16, 188-196. https://doi.org/10.18493/kmusekad.43968

Newson, M. (2017). Football, Fan Violence, and Identity Fusion. International Review for the Sociology of Sport. https://doi.org/10.1177/1012690217731293

Niiler, E. (2018). World Cup 1938: When Nazi Germany Forced Austrians to Play For Them-And Lost. Retrieved from https://www.history.com/news/world-cup-nazi-germany-forced-austrian-players-lost

Özgen, C., \& Argan, M. (2017). The Turkish Version of the Grandiose Narcissism Scale: A Validity and Reliability Study of Football Team Fans, 4(3). https://doi.org/10.30958/ajspo.4.3.1

Özgen, C., \& Balci, V. (2017). An investigation on reasons of the decrease in number of spectators in 2014-2015 Turkish football league season from the perspectives of spectators. Journal of Physical Education \& Sports Science/Beden Egitimi ve Spor Bilimleri Dergisi, 11(2). 
Rookwood, J., \& Pearson, G. (2012). The hoolifan: Positive fan attitudes to football 'hooliganism'. International Review for the Sociology of Sport, 47, 149-164. https://doi.org/10.1177/1012690210388455

Spaaij, R. (2008). "Men like us, boys like them": Violence, masculinity, and collective identity in football hooliganism. Journal of Sport \& Social Issues, 32, 369-392. https://doi.org/10.1177/0193723508324082

Tinaz, C., Mefharet, E., \& Arda, C. (2015). The fans against violence.National Report Turkey.

UEFA, 22 November 2002. Besiktas mourn fan's death. https://es.uefa.com/uefaeuropaleague/news/newsid=259599.html

Yücel, S. A., Atalay, A., \& Gürkan, A. (2015). SpordaŞiddet ve Saldırganlı̆̆ıEtkileyenUnsurlar, Uluslararası HakemliPsikiyatri ve Psikolojiaraştırmaları Dergisi, 2(2).

\section{Copyrights}

Copyright for this article is retained by the author(s), with first publication rights granted to the journal.

This is an open-access article distributed under the terms and conditions of the Creative Commons Attribution license which permits unrestricted use, distribution, and reproduction in any medium, provided the original work is properly cited. 